\title{
Role of Prophylactic Antibiotic Administration in Severe Acute Pancreatitis: A Meta-Analysis
}

\author{
Guang-Su Xiong ${ }^{a, b}$ Shu-Ming Wu ${ }^{a, b}$ Zheng-Hua Wang ${ }^{a, b}$ \\ ${ }^{a}$ Renji Hospital, Shanghai Second Medical University, and ${ }^{b}$ Shanghai Institute of Digestive Disease, \\ Shanghai, PR China
}

\section{Key Words}

Pancreatitis, severe acute $\cdot$ Antibiotics, prophylactic ·

Meta-analysis

\begin{abstract}
Objective: To carry out a meta-analysis of published studies in order to evaluate the clinical efficacy of prophylactic antibiotics in severe acute pancreatitis (SAP). Material and Methods: MEDLINE, China Biological Medicine, Embase and Cochrane Data Base for Systematic Reviews were searched for randomized controlled trials on the efficacy of prophylactic antibiotics in patients with SAP from 1966 to 2004. Six studies met our inclusion criteria. Two authors (G.S.X. and Z.H.W.) independently extracted the following data from these studies: trial design, characteristics of participants and outcomes. Data were analyzed by Revman 4.2 software. Results: In patients with SAP, prophylactic antibiotics, including broadspectrum antibiotics that usually achieve therapeutic pancreatic tissue levels, did not reduce pancreatic infection (relative risk, RR, $0.77,95 \%$ confidence interval 0.48 $1.24, p=0.28$ ), surgical intervention (RR $0.84,95 \%$ confidence interval $0.40-1.74, p=0.64$ ) and mortality rate (RR $0.54,95 \%$ confidence interval $0.28-1.04, p=0.07$ ). Conclusions: Prophylactic antibiotic administration is not an
\end{abstract}

appropriate treatment strategy in patients with SAP, it should be limited in patients with pancreatic necrosis, as demonstrated by computerized tomography.

Copyright (C 2006 S. Karger AG, Basel

\section{Introduction}

Acute pancreatitis is a common medical emergency. Its incidence in China has been reported to be increasing. Approximately 20\% of the patients develop severe acute pancreatitis (SAP), resulting in high mortality. Although a severe complication of SAP is pancreatic infection, which has a mortality of about $80 \%$ [1], the use of antibiotics in SAP remains controversial. Initial studies using prophylactic antibiotics in unselected patients with acute pancreatitis failed to show any favorable effect on morbidity or mortality [2-4]. This was probably due to the use of antibiotics that do not achieve therapeutic levels in pancreatic tissue. A meta-analysis [5] of eight randomized controlled trials (RCT) [2-4, 6-10] in 1998 showed a beneficial effect of antibiotics in reducing the mortality of SAP, but other meta-analyses of RCTs [11-13] showed conflicting results. We, therefore, decided to conduct a new meta-analysis of published RCTs to determine the role of antibiotics in SAP.

\section{KARGER}

Fax +4161306 1234 E-Mail karger@karger.ch www.karger.com
(C) 2006 S. Karger AG, Basel

$1011-7571 / 06 / 0152-0106 \$ 23.50 / 0$

Accessible online at:

www.karger.com/mpp
Shu-Ming Wu

Shanghai Institute of Digestive Disease

Renji Hospital, Shanghai Second Medical University

Shanghai 200001 (PR China)

Tel. +861380198 8308, Fax +862163266027, E-Mail xgs2002@hotmail.com 
Table 1. Demographic data of studies included in meta-analysis for prophylaxis/control subjects

\begin{tabular}{|c|c|c|c|}
\hline Reference & Patients & Severity & Use of antibiotics \\
\hline Pederzoli et al. [6] & $41 / 33$ & necrosis on CT or ultrasound & imipenem, $0.5 \mathrm{~g}$ every $8 \mathrm{~h}$ \\
\hline Sainio et al. [8] & $30 / 30$ & $\begin{array}{l}\mathrm{CRP}>120 \mathrm{mg} / \mathrm{l} \text { and low contrast } \\
\text { enhancement on CT }\end{array}$ & cefuroxime, $4.5 \mathrm{~g} /$ day \\
\hline Delcenserie et al. [9] & $11 / 12$ & $\geq 2$ fluid collection on $\mathrm{CT}$ & $\begin{array}{l}\text { ceftazidime, } 2 \text { g every } 8 \mathrm{~h} \text {; amikacine, } 5 \mathrm{mg} \cdot \mathrm{kg}^{-1} \\
\text { every } 12 \mathrm{~h} \text {; and metronidazole, } 0.5 \mathrm{~g} \text { every } 8 \mathrm{~h}\end{array}$ \\
\hline Schwarz et al. [10] & $13 / 13$ & sterile necroses on $\mathrm{CT}$ & $\begin{array}{l}\text { ofloxacin, } 0.2 \mathrm{~g} \text { twice a day; metronidazole, } 0.5 \mathrm{~g} \\
\text { twice a day }\end{array}$ \\
\hline Spicak et al. [11] & $20 / 21$ & necrosis on CT or CRP $>190 \mathrm{mg} / \mathrm{l}$ & meropenem, $0.5 \mathrm{~g}$ every $8 \mathrm{~h}$ \\
\hline Isenmann et al. [12] & $58 / 56$ & $\begin{array}{l}\mathrm{CRP}>150 \mathrm{mg} / \mathrm{l} \text { and/or necrosis } \\
\text { on } \mathrm{CT}\end{array}$ & $\begin{array}{l}\text { ciprofloxacin, } 0.4 \mathrm{~g} \text { twice a day; metronidazole, } 0.5 \mathrm{~g} \\
\text { twice a day }\end{array}$ \\
\hline
\end{tabular}

Table 2. Outcome of studies in the meta-analysis for prophylaxis/control subjects

\begin{tabular}{llllll}
\hline Reference & Patients & $\begin{array}{l}\text { Pancreatic } \\
\text { infection }\end{array}$ & $\begin{array}{l}\text { Extrapancreatic } \\
\text { infection }\end{array}$ & $\begin{array}{l}\text { Surgical } \\
\text { intervention }\end{array}$ & $\begin{array}{l}\text { Mor- } \\
\text { tality }\end{array}$ \\
\hline Pederzoli et al. [6] & $41 / 33$ & $5 / 10$ & $6 / 16$ & $12 / 11$ & $3 / 4$ \\
Sainio et al. [8] & $30 / 30$ & $9 / 12$ & $10 / 25$ & $7 / 14$ & $1 / 7$ \\
Delcenserie et al. [9] & $11 / 12$ & $0 / 7$ & - & - & $1 / 3$ \\
Schwarz et al. [10] & $13 / 13$ & $8 / 7$ & $4 / 6$ & - & $0 / 2$ \\
Spicak et al. [11] & $20 / 21$ & $5 / 7^{\mathrm{a}}$ & - & $4 / 5$ & $4 / 5$ \\
Isenmann et al. [12] & $58 / 56$ & $7 / 5$ & $13 / 13$ & $10 / 6$ & $3 / 4$ \\
\hline
\end{tabular}

${ }^{\text {a }}$ Extrapancreatic infection included.

\section{Material and Methods}

\section{Inclusion Criteria}

The inclusion criteria for the meta-analysis were RCTs in which prophylactic antibiotic therapy was evaluated in SAP, in comparison with placebo therapy and best supportive care. The antibiotics evaluated should achieve therapeutic levels in pancreatic tissue. The trial had to contain information about the diagnosis of SAP and at least one of the following outcomes: pancreatic infection, extrapancreatic infection, surgical intervention and mortality.

\section{Search Strategy for Identification of Studies}

Using the MEDLINE database, 2 of the authors (G.S.X. and Z.H.W.) independently conducted a fully recursive literature search for RCTs from January 1966 to August 2004. Keywords for the search were pancreatitis, acute pancreatitis, and the combination of these two words. In addition to MEDLINE database, Embase, the Cochrane Database of Systematic Reviews, and China Biological Medicine Disk (CBM-disk) were searched. We searched for publications in abstract form using article references and official proceedings of major North American, European and Chinese scientific meetings. Initially, 15 RCTs were identified [2-4, 6-17], only six of them [6, 8-12] fulfilled the inclusion criteria, three [2-4] did not achieve therapeutic levels of antibiotics in pancreatic tissue, another three [14-16] compared prophylaxis between two different antibiotics, one [13] compared early imipenem treatment with delayed treatment, another [7] assessed the role of selective gastrointestinal tract decontamination and two publications $[12,17]$ referred to the same study. Equally important, a review of bibliographies of all selected articles and communication with experts in the specialty failed to identify additional relevant studies. Thus information from the six studies yielded 338 patient data for this analysis (table 1).

\section{Data Extraction}

The 2 investigators independently abstracted the following data from all the studies: study design, population, severity of illness, antibiotics used and outcomes. The data were recorded on standardized forms. The APACHE II score, Ranson score, C-reactive protein (CRP), or computed tomography (CT) scans were used to quantify the severity of pancreatitis (table 2).

\section{Data Analysis}

Pancreatic infection, extrapancreatic infection, surgical intervention and mortality were binary variables. Study endpoints were calculated by intention to treat. Data analysis was performed using the random effects model with meta-analysis software (RevMan 4.2, Cochrane Collaboration). The relative risk (RR) is presented with $95 \%$ confidence intervals. Heterogeneity between trials was determined using $\chi^{2}$ test, with $\mathrm{p} \leq 0.05$ indicating significant heterogeneity. 
Table 3. $R R$ and $Z$ value for pancreatic infection, extrapancreatic infection, surgical intervention, and mortality

\begin{tabular}{llllll}
\hline Outcome & Studies & RR & $\begin{array}{l}\text { 95\% confidence } \\
\text { interval }\end{array}$ & $\chi^{2}$ value & Z value \\
\hline Pancreatic infection & 6 & 0.77 & {$[0.48,1.24]$} & 7.54 & 1.09 \\
Extrapancreatic infection & 4 & 0.52 & {$[0.31,0.88]$} & 6.09 & $2.45^{*}$ \\
Surgical intervention & 3 & 0.84 & {$[0.40,1.74]$} & 3.64 & 0.47 \\
Mortality & 6 & 0.54 & {$[0.28,1.04]$} & 3.0 & 1.83 \\
\hline
\end{tabular}

$* \mathrm{p}=0.01$.

\section{Results}

$\mathrm{RR}$ and $95 \%$ confidence intervals for pancreatic infection, extrapancreatic infection, surgical intervention, and mortality are shown in table 3 and figure 1 .

\section{Pancreatic Infection}

Information on the incidence of pancreatic infection was available for all the studies. There was no significant difference in the incidence between the prophylaxis and control group $(\mathrm{RR}=0.77,95 \%$ confidence interval $0.48-1.24, p=0.28$, fig. 1$)$. The test result for heterogeneity between the studies was not significant $(\mathrm{p}=$ $0.18)$.

\section{Extrapancreatic Infection}

Information on the incidence of extrapancreatic infection was available for 4 of the studies included. There was a significantly lower risk of extrapancreatic infection in prophylaxis groups compared to control groups $(\mathrm{RR}=$ $0.52,95 \%$ confidence interval $0.31-0.88, p=0.01$, fig. 1 ). The test result for heterogeneity between the studies was not significant $(\mathrm{p}=0.16)$.

\section{Surgical Intervention}

Information on the incidence of surgical intervention was available for 3 studies. There was no significant difference in the incidence between the prophylaxis and control groups $(\mathrm{RR}=0.84,95 \%$ confidence interval 0.40 $1.74, p=0.64$, fig. 1$)$. The test result for heterogeneity between the studies was not significant $(p=0.16)$.

\section{Mortality}

All studies reported on hospital mortality. There was no significant difference in hospital mortality between the prophylaxis and control group $(\mathrm{RR}=0.54,95 \%$ confidence interval $0.28-1.04, p=0.07$, fig. 1). The test result for heterogeneity between the studies was not significant $(\mathrm{p}=0.69)$.

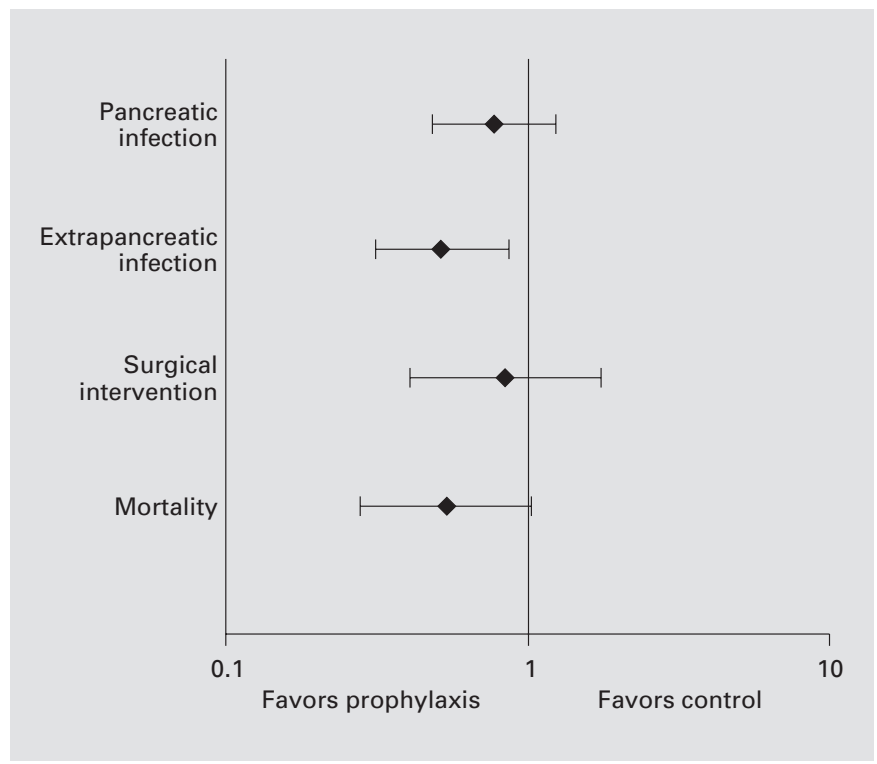

Fig. 1. Risk of pancreatic infection, extrapancreatic infection, surgical intervention, and mortality.

\section{Discussion}

The practice of antibiotic prophylaxis in acute pancreatitis is widespread. A survey of 1,103 surgeons in the United Kingdom and Ireland showed that prophylactic treatment with antibiotics was used by $88 \%$ of the 528 responding surgeons and $24 \%$ of them used it in all patients [18]. A similar survey has not been conducted in China; most probably the results would be the same. Mild acute pancreatitis is a short-lived and self-limiting disease. Hence the practice of giving antibiotics to all patients with acute pancreatitis may not be justified. But it remains uncertain as to whether or not patients with SAP benefit from prophylactic antibiotics.

The meta-analysis we conducted on all 6 RCTs did not show a positive benefit from prophylactic antibiotics, for 
main clinical outcomes, such as pancreatic infection, surgical intervention, and mortality in patients with SAP even when therapeutic levels in pancreatic tissue were achieved. This finding is consistent with three trials conducted in the 1970s, using ampicillin [2-4]. However, these studies have been justifiably criticized because the patients had mild pancreatitis, as evidenced by a zero mortality rate in the control group. Furthermore, ampicillin is a poor choice for use in prophylaxis because it has been shown that it does not penetrate into pancreatic tissue, and its spectrum of activity is limited against the organisms most commonly found in infected necrosis. However, second- and third-generation cephalosporins, piperacillin, mezlocillin, 4-quinolone, metronidazole, and imipenem have been shown to reach therapeutic levels in pancreatic tissue, both in animal and human studies $[19,20]$.

Equally, the trial by Pederzoli et al. [6] failed to demonstrate a significant reduction in mortality for sepsis, although the mortality in the placebo group $(12.1 \%)$ was slightly higher than that in the antibiotic group (7.3\%). A meta-analysis of 8 RCTs that showed a positive benefit for antibiotics in reducing mortality recommended that all patients with SAP be treated with broad-spectrum antibiotics that achieve therapeutic levels in pancreatic tissue [5].

However, serious concerns exist about such a practice. In a study by Beger et al. [21] carried out before antibiotic prophylaxis became widely used, organisms cultured from infected pancreatic necrosis were predominantly of gastrointestinal origin (Escherichia coli and Bacteroides spp.). The microbiology profile of a more recent study, comparing perfloxacin and imipenem in pancreatic necrosis, was dominated by methicillin-resistant Staphylococcus aureus and Candida spp. [14]. This development is important because evidence is beginning to emerge which indicates that infection with fungi and antibioticresistant organisms is associated with a significantly increased mortality [22].

A more recent double-blind multicenter study on the use of antibiotic prophylaxis in acute pancreatitis [12] aptly demonstrated that there is no beneficial effect of antibiotic prophylaxis for protecting against the risk of developing infected pancreatic necrosis. Regarding the secondary endpoints of the study such as incidence of death, incidence of extrapancreatic infection, surgical treatment for necrotizing pancreatitis, duration of stay in the intensive care unit, duration of hospitalization, there were no statistical differences between the antibiotic and the placebo groups.
The study by Isenmann et al. [12] is the most powerful study with negative impact on the present meta-analysis, but it has been criticized for the use of CRP to stratify necrotizing pancreatitis. Furthermore, the studies included are of relatively poor quality, with only one study being double-blind, and had differing inclusion and exclusion criteria for the severity of disease. An additional limitation is that a small number of patients were included in the meta-analysis. The overall small sample size led to wide confidence intervals. Also, it is possible that studies with negative results might have remained unpublished, leading to publication bias.

A Cochrane review of four studies undertaken by Bassi et al. [23] showed that despite variations in drug agent, case mix, duration of treatment and the studies not being double-blinded, strong evidence existed that intravenous antibiotic prophylactic therapy of 10-14 days decreased the risk of superinfection of necrotic tissue and mortality in patients with SAP with proven pancreatic necrosis at CT. Hence, they recommend the use of broad-spectrum antibiotics active against enteric organisms. It is consistent with the guidelines on the surgical management of acute pancreatitis provided by the International Association of Pancreatology [24]. The warning that it may not improve survival reflects the uncertainty of the evidence that has emerged from the trials undertaken to date. Based on current evidence, patients with necrosis proved at CT are likely to benefit from an appropriate use of broad-spectrum antibiotics, especially if necrosis is large (more than $30 \%$ of pancreatic volume) and the treatment is started early in the course of disease.

\section{Conclusion}

Based on our meta-analysis, prophylactic antibiotic administration is not an appropriate treatment strategy in unselected patients with SAP, it should only be limited to patients with pancreatic necrosis confirmed by $\mathrm{CT}$.

\section{Acknowledgments}

Thanks to Dr. Eduardo Villatoro, Gastroenterology Research Fellow of Derby Medical School, Derby City General Hospital, for his technical assistance and for making available to us an English translation of the paper by Schwarz et al. [10]. 


\section{References}

$\checkmark 1$ Renner IG, Savage WT 3rd, Pantoja JL, Renner VJ: Death due to acute pancreatitis: a retrospective analysis of 405 autopsy cases. Dig Dis Sci 1985;30:1005-1018.

-2 Howes R, Zuidema GD, Cameron JL: Evaluation of prophylactic antibiotics in acute pancreatitis. J Surg Res 1975;18:197-200.

$\checkmark 3$ Craig RM, Dordal E, Myles L: The use of ampicillin in acute pancreatitis (letter). Ann Intern Med 1975;83:831-832.

-4 Finch WT, Sawyers JL, Schenker S: A prospective study to determine the efficacy of antibiotics in acute pancreatitis. Ann Surg 1976;183: 667-671.

$\checkmark 5$ Golub R, Siddiqi F, Pohl D: Role of antibiotics in acute pancreatitis: a meta-analysis. J Gastrointest Surg 1998;2:496-503.

$\checkmark 6$ Pederzoli P, Bassi C, Vesentini S, Campedelli A: A randomized multicenter clinical trial of antibiotic prophylaxis of septic complications in acute necrotizing pancreatitis with imipenem. Surg Gynecol Obstet 1993;176:480-483.

7 Luiten EJ, Hop WC, Lange JF, Bruining HA: Controlled clinical trial of selective decontamination for the treatment of severe acute pancreatitis. Ann Surg 1995;222:57-65.

$\checkmark 8$ Sainio V, Kemppainen E, Puolakkainen P, Taavitsainen M, Kivisaari L, Valtonen V, Haapiainen R, Schroder T, Kivilaakso E: Early antibiotic treatment in acute necrotising pancreatitis. Lancet 1995;346:663-667.

$\checkmark 9$ Delcenserie R, Yzet T, Ducroix JP: Prophylactic antibiotics in treatment of severe acute alcoholic pancreatitis. Pancreas 1996;13:198201.

-10 Schwarz M, Isenmann R, Meyer H, Beger HG: Antibiotic use in necrotizing pancreatitis: results of a controlled study. Dtsch Med Wochenschr 1997;122:356-361.
11 Spicak JHS, Cech P, Hoskovec D, Kostka R, Leffler J, et al: Antibiotic prophylaxis in severe acute pancreatitis: randomised multicenter prospective trial with meropenem. Pancreatology 2003;3:220

12 Isenmann R, Runzi M, Kron M, Kahl S, Kraus D, Jung N, Maier L, Malfertheiner P, Goebell H, Beger HG: Prophylactic antibiotic treatment in patients with predicted severe acute pancreatitis: a placebo-controlled, doubleblind trial. Gastroenterology 2004;126:9971004.

13 Nordback I, Sand J, Saaristo R, Paajanen H Early treatment with antibiotics reduces the need for surgery in acute necrotizing pancreatitis - a single-center randomized study. J Gastrointest Surg 2001;5:113-118; discussion 118-120.

14 Bassi C, Falconi M, Talamini G, Uomo G, Papaccio G, Dervenis C, Salvia R, Minelli EB, Pederzoli P: Controlled clinical trial of pefloxacin versus imipenem in severe acute pancreatitis. Gastroenterology 1998; 115:15131517.

15 Manes G, Rabitti PG, Menchise A, Riccio E, Balzano A, Uomo G: Prophylaxis with meropenem of septic complications in acute pancreatitis: a randomized, controlled trial versus imipenem. Pancreas 2003;27:e79-e83.

16 Liang LY, He YX, Du P, Jin XY, Shang BC: Prophylaxis with imipenem of septic complications in severe acute pancreatitis: a clinic trial of 28 patients. Xinan Guofang Yiyao 2003; 13:621-622.
17 Isenmann RRM, Kron M, Sander S, Goebell H, Beger HG: Ciprofloxacin/metronidazole in patients with severe acute pancreatitis - results of a double-blind, placebo-controlled multicentre trial. Pancreas 2002;25:433.

18 Powell JJ, Campbell E, Johnson CD, Siriwardena AK: Survey of antibiotic prophylaxis in acute pancreatitis in the UK and Ireland. $\mathrm{Br} \mathrm{J}$ Surg 1999;86:320-322.

19 Bradley EL 3rd: Antibiotics in acute pancreatitis: current status and future directions. Am J Surg 1989;158:472-477; discussion 477-478.

20 Trudel JL, Wittnich C, Brown RA: Antibiotics bioavailability in acute experimental pancreatitis. J Am Coll Surg 1994; 178:475-479.

21 Beger HG, Bittner R, Block S, Buchler M: Bacterial contamination of pancreatic necrosis: a prospective clinical study. Gastroenterology 1986;91:433-438.

22 Gotzinger P, Wamser P, Barlan M, Sautner T, Jakesz R, Fugger R: Candida infection of local necrosis in severe acute pancreatitis is associated with increased mortality. Shock 2000; 14 : 320-323; discussion 323-324.

23 Bassi C, Larvin M, Villatoro E: Antibiotic therapy for prophylaxis against infection of pancreatic necrosis in acute pancreatitis. Cochrane Database Syst Rev 2003:CD002941.

24 Uhl W, Warshaw A, Imrie C, Bassi C, McKay CJ, Lankisch PG, Carter R, Di Magno E, Banks PA, Whitcomb DC, Dervenis C, Ulrich CD, Satake K, Ghaneh P, Hartwig W, Werner J, McEntee G, Neoptolemos JP, Buchler MW: IAP Guidelines for the Surgical Management of Acute Pancreatitis. Pancreatology 2002;2: 565-573. 